instrument of self-education. Mr. Munford is at his best when he writes of the administrative problems of staffing, bookstocks, buildings and methods, while throughout he combines the balance of an economist with the ideals of a social reformer. A most interesting appendix on 'Mechanics' Institutes and Public Libraries" is contributed by Mrs. Joan Edmundson.

\section{Organic Chemistry}

By Dr. P. J. Durrant. Pp. xi+544. (London, New York and Toronto : Longmans, Green and Co., Ltd., 1950.) $18 s$.

$\mathrm{T}$ HE greater part of this book, actually twenty seven of its thirty chapters, deals with the preparation and properties of organic compounds, interspersed with directions for practical work in a way long made familiar to us by the texts of Perkin and Kipping and of J.B. Cohen. This section is well written, is up to date and covers the ground required for the Advanced and Scholarship Examinations of the General Certificate of Education.

The author has supplemented this conventional treatment by adding some valuable summaries born of his scholarship and experience. Thus, Chapter 1 is a simple but masterly account of the atomic theory and modern views on chemical bonding. It should afford enjoyable and profitable reading for all sorts of chemists. Again, in Chapter 29 the author assembles, discusses and classifies in tabular form the reactions treated in the book. 'This is a first-rate piece of work and facilitates the study of the various functional groups. Finally, Chapter 30 deals with the production of many compounds on the industrial scale.

At the end of the volume there are thirty pages of questions with answers to the numerical problems. Students should find this book for examination purposes extraordinarily helpful.

G. F.

Short-Wave Radio and the lonosphere

With Special Reference to Everyday Professional and Amateur Problems of Short-Wave Transmissicn and Reception. By T. W. Bennington. Second edition. Pp. 138. (London: Iliffe and Sons, Ltd., 1950.) 10s. 6d. net.

A. BENNINGTON'S little book, "Radio Waves $\mathrm{I}$ and the Ionosphere", which appeared some eight years ago (see Nature, 154, 413; 1944), aimed at providing a simple, non-mathematical account of the nature of the ionosphere and of the way it influences the propagation of radio waves. The present edition, with an amended title, the scope of which is similar to that of its predecessor on which it is based, has been completely re-written and extended in the light of knowledge acquired in the intervening years.

After an introductory chapter in which the propagation characteristics of radio waves at various frequencies are described, the author proceeds to describe the mode of formation of the various layers of the ionosphere by the sun's radiation, the method of measuring their ionization density and effective height and how these characteristics vary diurnally, seasonally, geographically and with the sunspct cycle. Consideration is then given to the methods by which this information is obtained from soundings made at vertical incidence; and it is applied to waves incident obliquely on the ionosphere. A whole chapter is devoted to the forecasting of the maximum usable frequency for communication between any two points on the earth's surface. This excellent chapter can be recommended to any radio engineer who desires to understand the basic principles and methods of use of forecast charts of the type now published by several national radio research organizations and which are widely used in the planning of radio communications.

The section dealing with amateur transmission will be helpful to the professional as well as the amateur in explaining some of the abnormalities so frequently observed in short-wave radio practice.

The book, which is well produced and illustrated, can be recommended to the radio communication engineer who desires to know more about those regions of the upper atmosphere which enable his signals to travel to the most distant parts of the earth; and also to the amateur, who will find the information provided of great value in helping him to pursue his hobby more usefully.

\section{Statistische Methoden}

Für Naturwissenschaftler, Mediziner und Ingenieure. Von Prof. Arthur Linder. (Lehrbücher und Monographien aus dem Gebiete der exakten Wissenschaften: Mathematische Reihe, Band 3.) Zweite, erweiterte Auflage. Pp. 238. (Basel : Verlag Birkhäuser, 195l.) 30 francs.

Pro

ROF. A. LINDER has made a valiant attempt to write a universal text-book of statistics covering mathematical foundations and the applications to many diverse sciences-a truly ambitious task. He has made, on the whole, a wise selection of subjectmatter, covering measures of location, dispersion and association, the elements of tests of significance (including $\chi^{2}$-tests), and of analysis of variance; regression, both ordinary- and multiple-, is dealt with rather fully, and the present second edition contains even such advanced topics as discriminant function analysis and the concept of 'generalized distance'.

Following an introduction, in which too much prior knowledge is assumed, there are two large parallel chapters, one on statistical measures, and the other on tests of significance. In the first, the statistics summarized above are developed, described and their computation illustrated by examples, while in Chapter 2 these same statistics are dealt with again from the point of view of their random sampling distributions and of tests of significance associated with them. This necessitates frequent repetitions of formulæ and back- and forwardreferences. A third chapter deals with the elements of analysis of variance, covering single classification (with equal numbers), double classification (with cell repetition) and three-way classification, which are well described. However, the difficult subject of why and when to use an interaction as 'error' is not adequately discussed. A fourth chapter (intended for the mathematically equipped reader) gives proofs for most of the distribution results used previously. 'The emphasis is on the geometry of the sample space rather than algebraic derivation.

This book will, no doubt, be of particular value in German-speaking countries. English-speaking readers will be glad to have authentic (and in many cases original) translations into German of well-known Anglo-Saxon statistical concepts, and those who have occasion to communicate about these with Germanspeaking statisticians will do well to adopt this book as a standard for translation. 